\title{
Old Japanese Capital Local Community Festivals: The Matsugasaki Case
}

\author{
Maya Keliyan \\ Institute of Philosophy and Sociology at BAS \\ Празници на локалната общност в старата японска столица: \\ Случаят с Мацугасаки
}

\section{Мая Келиян}

Институт по философия и социология при БАН

\begin{abstract}
Author note:
Maya Keliyan (D) https://orcid.org/0000-0002-1365-2804
\end{abstract}

Maya Keliyan is Professor, D.Sc. at Communities and Identities Department, Institute of Philosophy and Sociology, Bulgarian Academy of Sciences, Sofia.

She has no known conflict of interest to disclose.

Correspondence, concerning this article should be addressed to Maya Keliyan, Sofia 1000, 4 Serdika str., Institute of Philosophy and Sociology. Email: mayakeliyan@ gmail.com

\section{Бележки за автора:}

Мая Келиян (iD) https://orcid.org/0000-0002-1365-2804

Мая Келиян е проф. д.с.н. в секция „Общности и идентичности” на Института по философия и социология при БАН, София.

Няма конфликт на интереси.

Кореспонденцията, свързана с тази статия да бъде адресирана до Мая Келиян, София 1000, ул. „Сердика” № 4, ИФС. Email: mayakeliyan@ gmail.com 


\begin{abstract}
The aim of the article is to explore the importance of local festivals for building and strengthening social ties and solidarity between local community members in the Matsugasaki district of the old Japanese capital Kyoto. The analysis is based on the results of qualitative surveys conducted by the author in 2012-2013, 2015-2016 and 2018-2019 at three local festivals. During all three periods, the Summer festival and the Obon (The festival of the Dead) were studied, and during the last period, the Autumn festival, which was restored after a seven-year break, was also examined. The enterprising local actors playing a leading role in the preservation, organization and performance of these festivals have been identified, characterizing their activities and motivation. The relationships between the native and the newcomers in the neighborhood are investigated, considering the problems between them, arising from the non-admission of the newcomers to participate in the organization and performance of Obon rituals. Conclusions are reached on the ways in which local traditions have been preserved and/or changed over the years, indicating the factors influencing these processes.
\end{abstract}

Keywords: local community, traditions, local festivals, native and newcomers, enterprising local actors.

\title{
Резюме
}

Целта на статията е да се изследва значението на местните празници за изграждане и укрепване на социалните връзки и солидарността между членовете на локалната общност в квартала Мацугасаки на старата японска столица Киото. Анализът се базира на резултати от качествени ЕСИ, проведени от автора през 2012-2013 г., 2015-2016 г. и 2018-2019 г. на три местни фестивала. И през трите периода са изучавани летният фестивал и празникът Обон (японската задушница), а през последния период е изследван и възстановеният след седемгодишно прекъсване есенен фестивал. Идентифицирани са предприемчивите местни актьори, които играят водеща роля в опазването, организирането и провеждането на тези празници, като са характеризирани тяхната дейност и мотивация. Проследени са взаимоотношенията между коренните жители на локалната общност и новодошлите, промените в техните взаимоотношения, както и проблемите помежду им, произтичащи от недопускането на новодошлите да участват в организацията и провеждането на Обон. Достига се до заключения за 
начините, по които местните традиции са съхранени и/или променени през годините, като са посочени факторите, въздействащи върху тези процеси.

Ключови думи: локални общности, традиции, местни празници, коренни жители и новодошли, инициативни местни актьори 


\section{Old Japanese Capital Local Community Festivals: The Matsugasaki Case}

"We, the Japanese, seek and find support in two things:

Traditions and collective action."

Words of the interviewed resident of the studied local community

\section{Japanese local community festivals}

Festivals (called in Japanese matsuri), as part of the cultural heritage of local communities, are among significant elements of local and national culture. They solidify relationships between individuals and their community, making spirit of belonging stronger; they intensify solidarity of the participants and shape their collective identity. Changes in local community bring about respective changes in matsuri and changes in matsuri, in turn are indicative for transformations in local community life. The article objectives are to study local festivals, their place and role in urban communities' lifestyle, to identify social actors playing leading roles in their preservation, organization, and performance, and to explain what kind of transformations in local identity and modifications in social networks have been caused by these processes. Analysis and conceptualization of research findings are based on theoretical framework of the project "Local festivals: A resource of local communities for coping with crises", funded by National Science Fund - Ministry of Education and Science of Republic of Bulgaria (KP-06-H45 / 5 from 30.11.2020).

The author understands the local community as a form of conviviality and belonging of an aggregate of individuals, situated in an established network of social relations (Keliyan, 2010, p. 43). The socially significant indicator, which determines the structure of the local community, is the shared and adjacent territory and the interconnectedness of the community members. What matters are not so much the physical and geographic traits, as the nature and quality of social relations. The real and symbolic boundaries of the community are rather important, as they mark individuals' membership and belonging to it. Japanese society has a developed community culture, which has been preserved over the centuries and continues to perform an important role and function even now, in postmodern society. Japan is a communitarian society (Etzioni, 1998, pp. 259-266), in which social responsibility and duty towards the group and the community are of paramount importance, despite the intense current of individualism that comes through Western influence, modernization, urbanization, mass culture, and the social transformations all of these provoke. 
Japanese local community as well as its structures, cannot be studied and understood without clarifying the peculiarities of the traditional Japanese family system: the institutions of ie (which literally means house, household) and dozoku. Ie is the basic social and economic structure of traditional Japanese society. The right to inherit it belongs to the eldest son, and all other children, after starting their own families, must leave the household and cease to be family members; as a rule there remain the eldest son, his wife and children, as well as his parents. The other brothers and sisters establish their own ie, which is in a subordinate hierarchical position of the main household, something like its branch. The groups of ie interconnected in a certain hierarchical dependence is called dōzoku. The main ie is entitled honke, and its branches - bunke. Ancestors, who became Shinto deities after their dead, are called dōzoku shin, i.e. deities of dōzoku; they could be worshiped only in religious ceremonies performed by the head of the honke. The 1947 Constitution affirms the nuclear family as the basic unit of society, but the cultural, religious, and informal functions of both the $i e$ and the dōzoku are, in a sense, still preserved even in modern Japan.

In Japan, apart from the formal, institutionalized, and legally established structure, the local community also creates a functioning network of informal structures, which build up, maintain, and develop certain types of relationships between members. The nature, structure and functions of the local community have been the subject of a thorough and in-depth analysis in previous studies (Keliyan, 2010, p. 48-81), which is why only some of their features will be briefly mentioned in this text. The informal structure of the local community, established in Japanese tradition and functioning today, is called chōnaikai, which literally means 'neighborhood association' (Ajisaka, 2012). In some regions it is known as jichikai or 'residential association', a designation that emphasizes autonomy, unlike the official administrative institutions established through law. The members of the local community are engaged in the numerous activities managed by the informal council, activities for which community leader is generally responsible. In various fields of activity the following organizations are created and function: groups for protection against natural disasters; groups for maintenance and cleaning of roads and local infrastructure; groups ensuring the security and safety of the residents; groups ensuring the socialization of the children; PTA (Parents and Teachers Associations); groups of people sharing common interests such as housewives, pensioners, youths, mothers, classmates, hobby groups, sport clubs, consumers associations, etc.; groups, organizing and conducting local festivals. In 2013 there were 300000 such 
neighborhood associations in Japan (Pekkanen et al., 2014, p. 1); in the last 30 years 90\% of the people residing on their territories were taking part in their activities.

One of the main tasks of the chonnaikai is maintaining the 'harmonious coexistence' of community members (Porcu, 2012, p. 90) and festivals are among main means for its achievement. Local festivals play important social role for community stability and historical perspective; they are not simply a manifestation (or reincarnation) of tradition; they are also a product of the pro-active attitude of local people, of their entrepreneurship. Festivals are constructing and strengthening the social bonds between community members, making obvious that living in a neighborhood is not simply a residence, but a question of belonging to some very special social group, with which people identify themselves (Ashkenazi, 1993). Religious practices, rituals, and festivals are building the foundation of social networks in local community; they are integrating a society (Durkheim, 2001). Through its regenerating power, the matsuri ensures continued cooperation between local people (Nelson, 1996, p. 133).

Traditions are something beyond invisible legacy of the past; they are also deeply connected with the way ancestors conceived the future of their families (Yanagita, 1988, p. 78). Traditions embedded in respective practices, rituals and festivals, consist both of elements deeply incorporated with the past as well as they include also new elements, invented from local community during its own socio-cultural changes (Bell, 1992). The later are indicative for local community creativity, demonstrating not only its response to socio-historical and cultural changes but also its understanding of its own identity and the ways of expressing it. The concept of 'innovation of tradition' (Hobsbawm, 1983, p. 1-12) designates the newly created values and norms of conduct that correspond to the arising requirements in a period of considerable transformations of the community; it should be noted that communities not only inherit but also create their traditions (Matsuda, 1998, p. 18-21). Traditions supply capacity of a society to maintain continuity, coherence and effective meanings and purposes both to individuals and to communities; it "certainly involves memory of the past but it does not mean necessarily slavery to the past". If society "loses tradition... it is left adrift without direction or purpose" (Bellah, 1983, p. 19).

On the one hand, matsuri are very adaptable to changes; on the other hand, they are very conservative, because unless they have to adapt themselves to new outside, or, in some cases to crisis situation, matsuri tend to be imitated and performed according to tradition 
(Plutschow et al., 1996, p. 2). It is because of these features of the festival that the changes in it are indicative of the changes in the entire life of the community and unequivocally confirm them. According to the results of numerous studies, conducted in the decades after World War II, local shrine festivals are regarded by general public less as religious observances than as community-enhancing events with considerable entertainment value (Bestor, 1989, p. 233255; Dore, 1958, p. 303-305; Plutschow et al., 1996; Lewis, 2018). Local people work together for organization and performance of matsuri and their common activities "reaffirm social network and promote a sense of community" (Nelson, 1996, p. 132). Some of local communities' festivals are religious but others have lost their religious character that they had in the past and in our days are concerned to be secular. In this article author is studying both types of festivals roles in local community and their influence on local people identity and solidarity.

In literature and researches dedicated to the subject, Japanese festivals are studied from different approaches: from point of view of religious studies, cultural studies, from historical, anthropological, ethnographical, and etc. approaches. In various sources it could be find detailed descriptions of different rituals, ceremonies, deities to which they are dedicated; there are discussions on the topics as divine and profane, religious and secular in the realm of matsuri and in connection to its organization and performance. Research approach to festivals used in the article is sociological; the center of the study is the local community as basic social group. It is a subject of different kind of activities and matsuri is an essential event, organized by local community; it is a result, a vital product of its own agency. Matsuri is deeply connected with local identity; on one side it is most visible expression of this identity to the outside world. On the other side, matsuri is preserving and transmitting this identity from generation to generation through the ages. Local people organizations, cooperation, common efforts, and sense of togetherness are essential for its organization and performance. The sociological approach to local community festivals aims to 'go beyond' purely ethnographic description and search of 'authenticity' of traditions. Author's research interest is geared towards social structures and interrelations, social-group actors, which enable organizing and carrying out festivals.

The author conducted field research on local festivals in community of Matsugasaki, Northern part of Kyoto city during 2012-2013, 2015-2016, and 2018-2019. During all three periods, the Summer festival and the Obon (The festival of the Dead) were studied, and 
during the third period, the Autumn festival, which was restored after a seven-year break, was also examined. Mainly qualitative methods were used, such as observations and participant observations; in-depth interviews and focus group discussions were conducted with local people, playing active roles in preservation, organization, performance, and re-vitalization of festivals; local community leaders, etc. Her research stays in Japan were supported by The Japan Foundation, The International Research Center for Japanese Studies (Nichibunken) in Kyoto, The Hakuho Foundation, and Kyoto University. She expresses her deep gratitude to Prof. Matsuda Motoji and Ms. Matsui Kazuko for their encouragement and support during all her research stays in Japan. She also gratefully appreciates the help and assistance of Mr. Iwasaki Takehiko's family during her field work in Matsugasaki.

\section{Local community of Matsugasaki: traditions and postmodern lifestyle}

Kyoto city, called also "the old capital", used to be Japan's capital and the emperor's residence from 794 until 1868. Its Northern part is a special place to investigate Japanese history and traditions and their presence in contemporary lifestyle. Our-day suburban areas are former villages; till 1970s these areas were covered with rice fields and most of the people were farmers; their history is closely connected with Japan's past. The name of Matsugasaki first appeared in 810. According to the legend, the village had deep and special relationships with the Japanese Imperial Household. When Emperor Kanmu settled in the capital, he ordered 100 families to be moved from Nara area and to establish the village of Matsugasaki. He lent them a field and a forest to grow rice for the imperial court. For that reason, it was requested that branch families - bunke will not be permitted to stay in the area and only main families - honke were allowed to remain in the village in order to produce needed crops. At the beginning of $14^{\text {th }}$ century village converted to Nichiren sect of Buddhism; this provoked the anger of the monks from nearby Hiezan monasteries, because the whole region around Kyoto belonged to Tendai sect of Buddhism.

"Matsugasaki is a very special district of Kyoto. It is the only place in the old capital whose inhabitants belong to the Nichiren sect of Buddhist. It is like a small island in the sea of the Tendai Buddhist sect, which has dominated Kyoto for centuries",

said in an interview a respondent living in a neighborhood next to Matsugasaki.

On the hills of the Matsugasaki mountain Eastern and Western hills, around which the village is located, are written two large Chinese characters - Myohō, whose meaning can be translated as „ultimate law permeating the universe". The words "Nam Myohō Renge Kyō" 
(Devotion to the Mystic Law of the Lotus Sutra/ Glory to the Dharma of the Lotus Sutra) are chanted within all forms of Nichiren Buddhism.

The village was incorporated in the boundaries of Kyoto city since 1931. Our days all population of Matsugasaki is about 8379 people, living in 4321 households; among them only 74 households or 210 people are descendants of native community's honke, and 4247 households are newcomers' families. The number of elderly people above 65 years old is 1492 or about $18 \%$ of the local population, which is less than average rate of elderly people in Japan (29\% of all population). But native community is ageing quickly and most of younger people are newcomers. The share of those under 15 years old is $11 \%$ of the population, and the amount of those between 15 and 64 years old $-65 \%$. The neighborhood is highly prestigious one; most of its residents belong to the middle and upper-middle classes and even to the Kyoto elites. Many residents have higher education and had graduated from prestigious universities, and some of them hold or have held in the past high positions as deans of university' faculties, heads of departments at leading national and private universities, principals of hospitals, etc. Matsugasaki is a beautiful neighborhood combining postmodern environment and traditional lifestyle with its old farmers' houses, remaining rice fields, streams flowing through the streets, which in the past were used to irrigate rice paddies, urban farming, Takaragaike lake and the greenery of surrounding mountains. It became fashionable townscape because of nearby Universities, subway, Kyoto International Conference Hall, business establishments, shops, wedding halls, churches, and trendy restaurants.

This process led to the increase of apartment blocks and of the population of newcomers, which in turn causes some kind of tension between natives and newcomers. Such kind of uneasiness is typical for local communities in former rural areas in Japan, and it is called "native-newcomer antinomy" (Robertson, 1991, pp. 41-43). In many areas in Kyoto and all over Japan only natives are allowed to participate in the community's religious festivals, like Obon in Matsugasaki. Exclusion of newcomers suggests symbolically they are not recognized as a part of 'real' community and its traditions. According to a participant in a focus group discussion:

"The development of Japanese cities after World War II led to similar controversies in a number of local communities. Natives do not perceive newcomers as 'true' and 'full' members of the community; they are particularly jealous of local traditions and unwilling to 
recognize newcomers as bearers of the latter. Even in cases where they have lived in this community for several decades... and despite the strong and repeatedly expressed desire of newcomers to participate in local celebrations"

This tendency may affect local festivals' performance in the future and may lead to some changes in traditions. Local community informal organizations in areas, where such contradictions exist, include in their social agendas activities to help smooth out relations between natives and newcomers.

Matsugasaki has very well established local community structures with its groups and organizations: the neighborhood is organized as Federation of Residential Associations jichirengōkai, including 17 such structures with functioning 24 different volunteering organizations. The local community also carries out its own economic activity. A few decades ago, a boat rental company was founded on Takaragaike lake, whose activities are maintained until now.

"It is not profitable from economic point of view, but the reason for its management is to continue the tradition of preserving the park around the lake as a center of leisure activities and to protect nature and ecological balance in the area",

shared an interviewee whose father was the founder of the company.

Middle classes representatives, such as retired teachers, engineers, doctors and university professors were active participants in above described structures. Many local people, after retirement, turn back to their native homes, following a U-turn type of migration. This type of returnees to their home places are active and motivated to keep their local traditions alive and organizing and performing matsuri is one of the ways to do that. Such cases were observed in Matsugasaki. These energetic pensioners helped in day-to-day activities such as safely moving students to school, patrolling busy streets and junctions in the area. They also regularly organized lectures for local elementary school students, introducing them to Matsugasaki history, culture, and traditions; they held celebrations where the students presented the lessons learned to the residents of the neighborhood. These activities were valued by local people as crucial for the upbringing of young people as well as for building their identity with local community.

According to the words of a local resident:

"The initiatives taken by some local people are important for bringing together natives and newcomers and for overcoming any contradictions that may arise between them." 
In 1974 local people established Matsugasaki Myohō Preservation Society to protect their traditions, to support local culture, to preserve old ceremonies, rituals, including their traditional dances daimoku odori and sashi odori. In 1977 was constructed the special building for this society, where all documents, archives, etc. are kept. It is also used for its members gatherings, to teach local children how to hit taiko drums, to sing traditional chants, and to dance traditional local dances. One of its members told about their activities:

"We gather every Thursday night from 7 p.m. to rehearse traditional chants we perform during Obon."

On $27^{\text {th }}$ and $28^{\text {th }}$ of October 2018, last Saturday and Sunday of October, was held the Autumn festival of the local Shinto shrine - Shingu jinja (picture 1).

\section{Picture 1}

\section{Matsugasaki Shingu jinja}

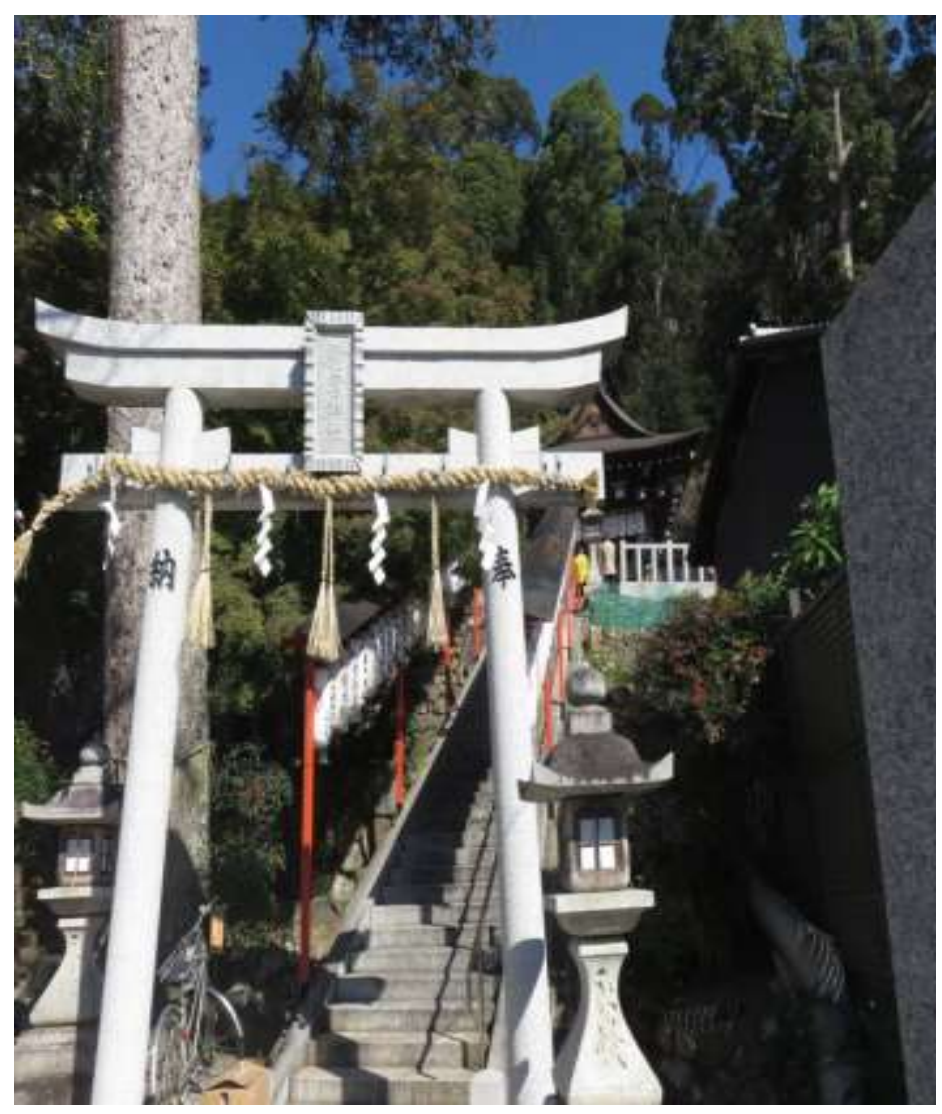

"By its origin it used to be Harvest Thanksgiving festival. In ancient times all the inhabitants of the neighborhood were farmers. Years ago it was organized by us, old community members, but because of our decreasing numbers, the festival was in decline... we stopped to perform its rituals...."

said interviewed native community member. 


\section{Picture 2}

\section{Imperial court dance}

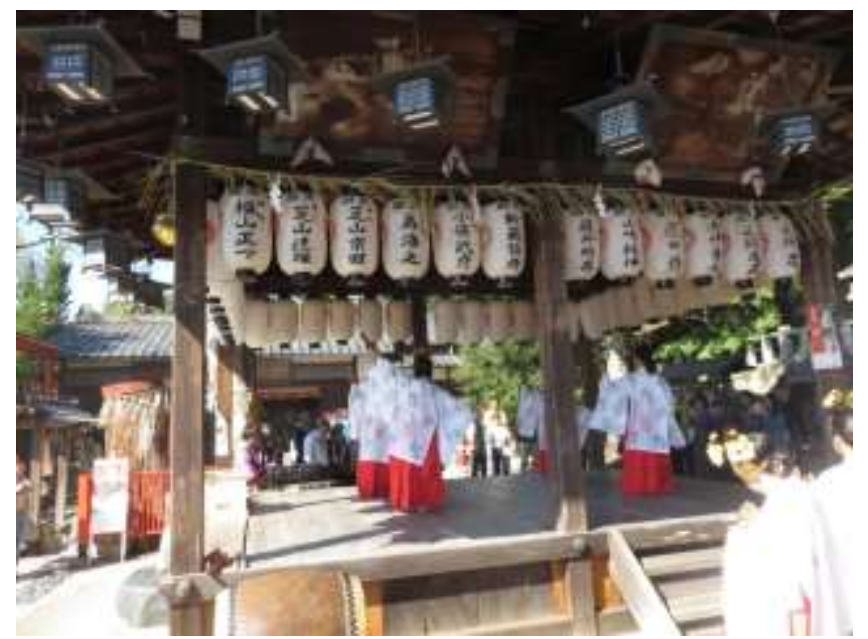

Seven years before my field work there, members of Local Primary School Fathers' Club, most of them newcomers, decided to revive the festival and after that it became very popular among local community. Festival started on 7:00 pm on October, $27^{\text {th }}$ with dance of mythical Lion, performed by shrine priest's brother.

After that eight fourth grade primary school girls, both from natives and newcomers families, performed imperial court old dances to the sounds of traditional music. All dances were dedicated to the Deities of Shingu jinja as gratitude for the good harvest.

\section{Picture 3}

\section{Blessing ceremony}

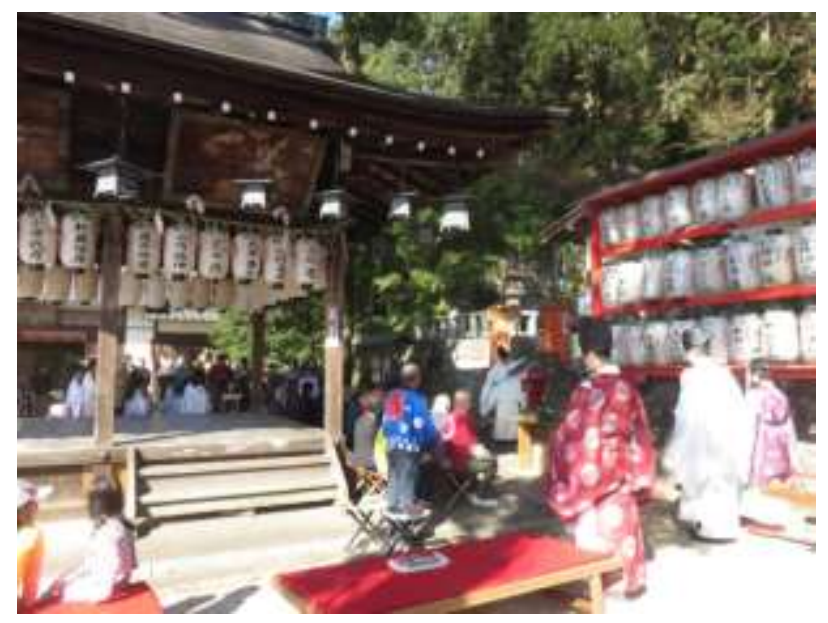

After dancing ritual, local people enjoyed food and drinks prepared from the festival organizers - Fathers' Club. The matsuri continued on the following day from 10:00 am with ceremony in which leaders of all 24 local community organizations where blessed by the Shingu jinja priest (picture 3). After the blessing ceremony, eight fourth grade primary school 
girls again performed imperial court old dances (picture 2) and people enjoyed food and drinks prepared by Fathers' Club (picture 4).

\section{Picture 4:}

Fathers' club selling food for matsuri

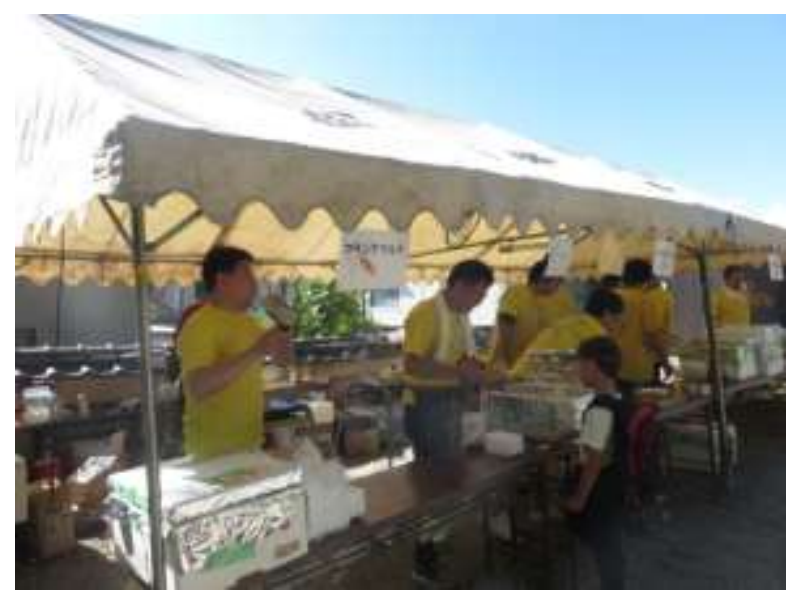

The festival ended on 1:30 pm with small parade of local primary school children (picture 5) with drum racing and towing carts with portable Shinto shrines, called mikoshi.

The Autumn festival is a small local festival, performed around Shingu jinja as a part of the annual round of rituals of this particular shrine. The festival includes some rituals like dances, prayers and blessings offered by the Shinto priest. It also is a part of public entertainment. Because the festival requires considerable organization and management, Fathers' Club together with local school and Shinto priest family took responsibilities, connected with its preparation and performance.

\section{Picture 5}

\section{Parade}

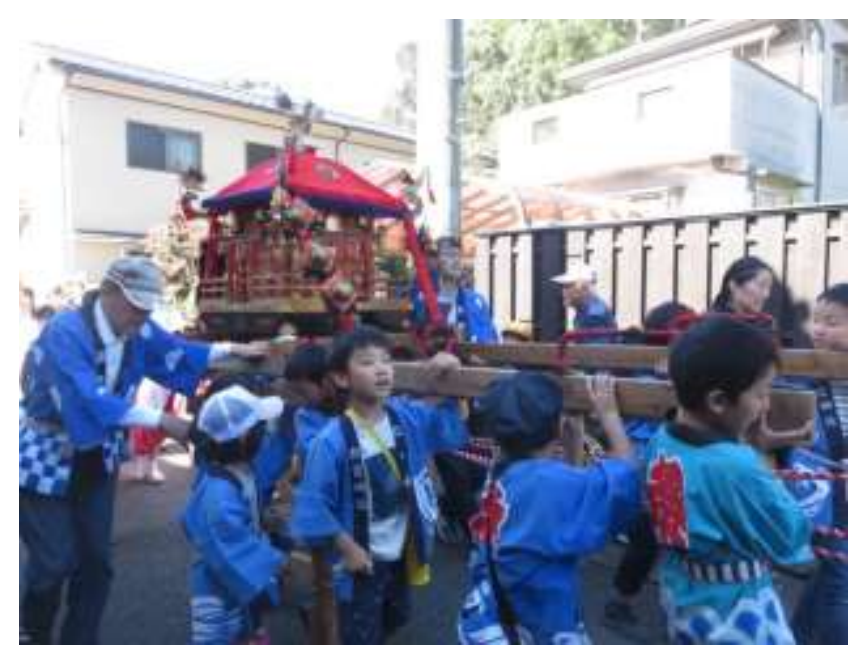


Apart from involving the local community structures, leaders of various local associations, and residents who otherwise would not take part in the activities of the neighborhood, the festival also serves as a compelling marker of the community's boundaries and identity, in particular through the mikoshi procession. In this regard, the matsuri is seen as a vehicle for affirming a sense of neighborhood identity through such symbols. Nelson (1996, p. 134) points to the 'transformative magic' derived from the revitalizing force attributed to festivals, which has its effects on communal awareness. Bestor (1989) observed that despite their Shinto character, these festivals were perceived by most of local residents as a secular event in which the explicit religious meaning was shifted to a social one.

In 2019, the Summer festival was held on $27^{\text {th }}$ of July (picture 6). It was organized by Matsugasaki primary school, with active participation of PTA, Fathers' Club, and with the crucial support of jichirengōkai. This was $21^{\text {st }}$ summer festival in Matsugasaki and it was a result of collaboration between natives and newcomers, a very good example of their fruitful cooperation and growing sense of belonging. Pupils from primary school were actively involved in matsuri cultural program. The festival was held from 4:00 till 8:30 pm and according to generalization of interviewed leader of jichirengōkai:

"About 800 local people enjoyed community atmosphere. We all had fun together, young and old, children, parents, natives and newcomers ".

\section{Picture 6}

\section{Summer festival poster}

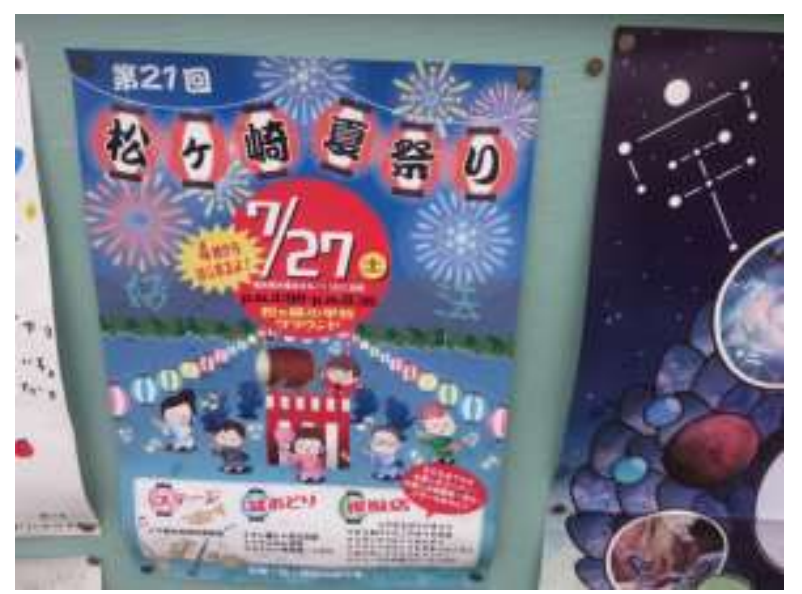

The festival started and ended with children dancing traditional sashi odori, which in our days is concerned to be non-religious dance and it is widely performed during local community celebrations by both natives and newcomers.

"This dance was registered as intangible folklore property by the city of Kyoto", 
said with pride a local resident attending the festival.

The festival, which is inextricably linked to the history and identity of this local community, its recognizable 'face' in front of the others is Obon - Buddhist celebration, dedicated to the honor of the spirits of ancestors. It is one of the largest and most revered festivals in the country and during its holding the Japanese take leave and return to their native places, where they visit family graves to pay tribute to their ancestors. On the evening of the last day of this celebration, on August $16^{\text {th }}$, in Kyoto giant ritual bonfires are lit on the surrounding mountains, signifying the moment when the spirits of deceased who are said to visit this world during Obon period are believed to be returning to the spirit world.

The festival also is called Gozan no okuribi which means Send-off fires on five mountains. Giant bonfires are lit starting at $8: 00 \mathrm{pm}$, each one with a distinctive shape. Three of the fires form giant Chinese characters, next one - the shape of a boat, and the other - the shape of the Shinto shrine gate (picture 7). Matsugasaki is famous with Myohō okuribi lighting giant fires in the form of two Chinese characters inscribed on Matsugasaki mountain East and West hills around which the neighborhood is located.

\section{Picture 7}

Kyoto Gozan okuribi poster

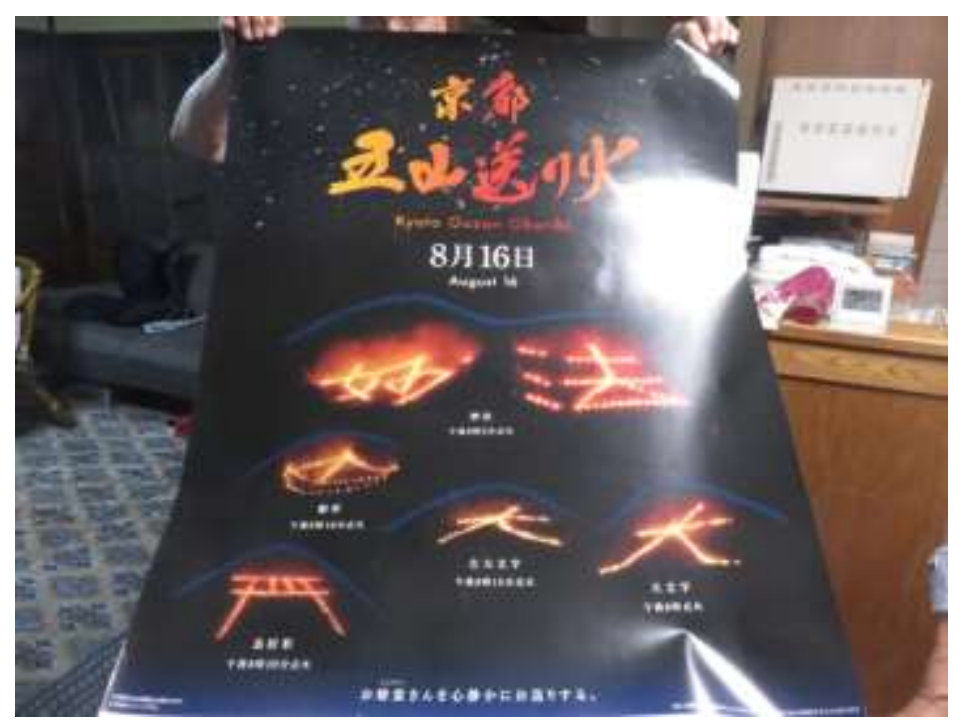

This festival is a part of Gozan no okuribi event. The lighting of the ritual fires of the five mountains is done by volunteers, but in each of these places is organized and conducted in a different way. Matsugasaki is the only neighborhood, where this festival is entirely the work of local people, their community and its informal structures. 


\section{Picture 8}

\section{Myo okuribi}

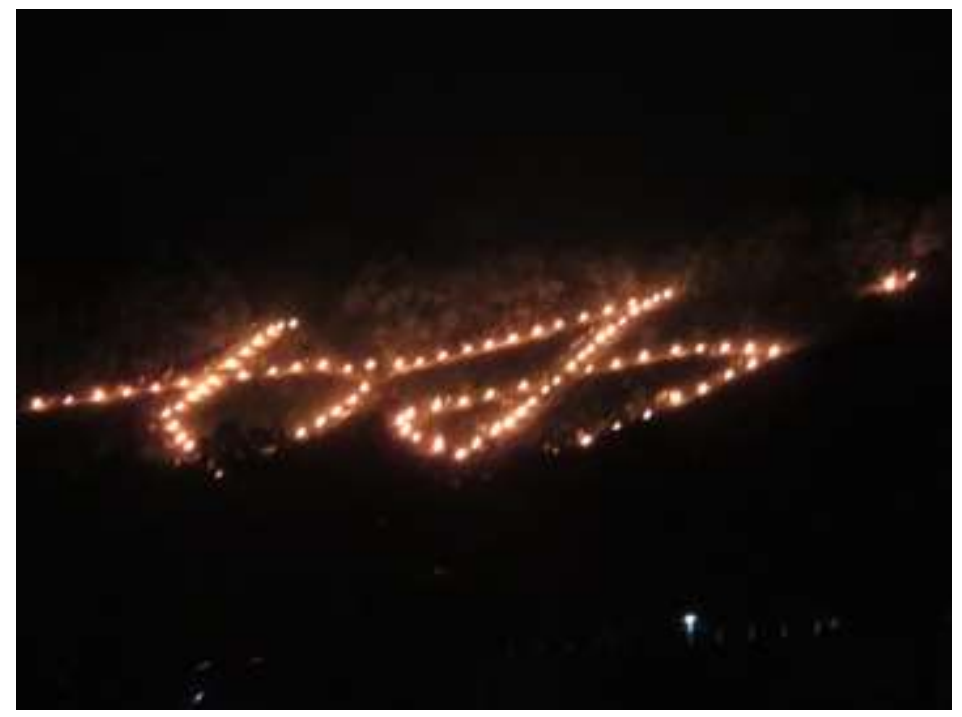

The author's field research was carried out in a local community, which organizes and conducts the Obon rituals in the area, where the Chinese character of myo is written on Matsugasaki mountain West hill (picture 8). All activities, connected with organization and realization of festival activities are held year-round on a voluntary basis and they are managed and carried out by Matsugasaki Myohō Preservation Society. A member of this society told during an interview that:

"The organization and performance of the festival is done entirely by local people. The municipality sponsors the event by providing money for the purchase of firewood for ritual fire."

During this festival local community members are performing special dances: already mentioned sashi odori and daimoku odori, also registered as intangible folklore property by Kyoto city. As mentioned by local residents during focus group discussion:

"According to the legend, a priest called Jitugan, converted his faith from Tendai to Nichiren sect of Buddhism. When he learned that all local residents had also converted, he was overjoyed and started dancing, chanting and drumming. People also joined him in dancing."

A document published in 1704 depicts the described dancing scene. Since then daimoku odori has been held on the 15th and 16th of August every year for about 600 years at local Yusenji temple. It is believed to be one of the oldest Obon dances in Japan. 
"This is considered to be a religious dance and only native Matsugasaki residents are allowed to perform it."

said a participant in the dance ritual.

As one of the biggest events Gozan no okuribi attracts many tourists in Kyoto, which stimulates the economy, but the locals are not particularly happy with the tourist flow, which hampers their everyday life and pollutes the city. Only old community members' households could participate in this event; newcomers' families are not allowed to take part in these activities. According to a Kyoto respondent:

"A close friend of mine has lived in Matsugasaki for more than fifteen years and her family wants to participate in the festival. But because they are not natives, they are not allowed to."

In this sense Myohō okuribi serves as a compelling marker of the community's boundaries and identity.

Obon activities in Matsugasaki included different ceremonies, held to pay respect to ancestors starting from August, $1^{\text {st }}$ till August, $16^{\text {th }}$. Locals visited cemeteries with flowers and sweets offerings and priest chanted in front of the tombs. Home Buddhist altars butsudan were decorated with vegetables, fruits and sweets as part of the preparation to invite ancestors back home on August, 13 and homemade lunch were offered to their souls during all Obon period. On August, 10 ${ }^{\text {th }}$ from 7:30 pm the final rehearsal of daimoku odori was held at Yusenji temple. On the early morning of August, $15^{\text {th }}$ dried woods were set on the fire beds to be prepared for the next day ritual Obon fire. From 8:00 pm daimoku odori was danced in the precincts of Yusenji temple. At 8:05 pm of the next day, August, $16^{\text {th }}$, a fire was set at designated fire beds to send off visiting ancestors' spirits back to Heaven.

After the ceremony with the lighting of the ritual fires, in which the author also joined during the observation she conducted, a participant in the ritual shared:

"I take part in the ceremony every year. But every time the command 'fire' is heard in the silence and darkness, my heart will pound with excitement."

After the bonfires were burnt out around 9:00 pm, daimoku odori was danced in the precinct of Yusenji temple. Men and women from native Matsugasaki households formed a circle and danced while chanting "Nam Myohō Renge Kyō" and drumming. After daimoku odori, all those presented at the local celebration, both residents of the neighborhood and guests, joined in the dance sashi odori. 
According to interviewed after the festival natives inhabitants:

"At the end of the ritual, we perform a dance in which all those present can join, both newcomers and tourists who have come to watch the holiday."

\section{Natives and newcomers: social bonds and community networks}

In Matsugasaki Myohō okuribi we can clearly observe significant differences between participants and visitors' attitudes toward this event, its meaning and importance. Local people take part in this festival's rituals to pay respect to their ancestors and they consider their participation as important part of their family and community history and identification. For Kyoto visitors Gozan okuribi is a tourist and cultural attraction. This difference between players' and watchers' approach to the festival is deepening during last decade, especially after rising the number of tourists visiting old Japanese capital. By its nature, this dissimilar view and understanding of the event is typical postmodern phenomenon connected with changes in urban environment, local communities and their lifestyle. In Matsugasaki newcomers are not accepted by natives as real local people so if they participate in the ritual, it will be like tourist attraction to them, not like real participation. The rituals performed during the festival express the respect of the living for their dead ancestors, who are in fact considered to be members of the $i e$, and through it - of the community. The main households (honke) of the newcomers are outside Matsugasaki, so they are not given the right to participate as performers during Myohō okuribi ceremonies with which the community honors their ancestors. Newcomers face social boundaries: they can join the festival only as observers.

Matsuri periodically renews the order and re-establishes the human bonds that constitute the communitas, providing the setting and occasion for grouping. Ritual change and evolution in matsuri is influenced by socio-economic changes. On the one hand, matsuri is very adaptable to changes, on the other hand, it is very conservative "unless they have to adapt themselves to new outside, or, in some cases to crisis situation, matsuri tend to be imitated and performed according to tradition" (Plutschow et al., 1996, p. 2). The main problem facing Matsugasaki local community is the aging of the native population, which has caused the change in the Autumn Festival. The newcomers not only could take part in this celebration, they are its main organizers, although they are actively supported by the structures of the local community and its native inhabitants. As for the Summer Festival, it 
has long since broken away from its religious roots in the distant past, taking place in every neighborhood, even the new residential complexes in the suburbs all over.

Despite of the above mentioned distinction between native and newcomer residents, there are other trends in the researched community that give hope for the common future of all its residents. In Matsugasaki, the studied Autumn festival and Summer festival are very good examples of traditional religious festivals that acquired non-religious, secular meaning. Both festivals are also illustration of collaboration between two types of local residents. People both from old and new community get together and work for successful performance of the celebrations, which is making social bonds between them stronger. In this way, on the one side, newcomers are feeling themselves as more closely connected with local traditions and, on the other side, old community members are more likely to perceive former ones as a part of local culture. Both festivals are also good examples of partnership between local primary school and community informal structures; they are working together to keep local traditions and to educate children about Matsugasaki history and culture. In terms of partnership with the local school, there is no controversy between the native inhabitants and the newcomers. It is important to remember that the newcomers develop their activities within inherited, well established and functioning community structures, which are created and maintained by the natives. Their initiatives fit into the already existing traditions and relations.

Pensioners who are still socially active are among the enterprising local actors in Matsugasaki. Retirees, who have returned to their homes after the end of their career in other parts of the country, are among the main organizers of many activities in the community and play an important role in preserving local festivals, customs and traditions. These initiative representatives of the native community, together with the active social actors from the newcomers, are the enterprising local people, on whom the community relies for the organization, holding, and preserving of the local festivals.

\section{Conclusions: traditions and their transformations}

The festivals studied, as well as the relationship between the natives and the newcomers in Matsugasaki, confirm that the traditions were not created once and for all. Traditions exist because they are in the process of constantly being created, reproduced and remodeled to acquire a clear appearance and to be "softened" so that they can absorb new and revitalizing elements. Local community is not a fixed social reality, it is changing; this is also 
true for its structures, identity and even for its traditions. Though its history it is continuously re-shaped, re-structured, and re-interpreted. It is important to pay attention to the relationships between native inhabitants and newcomers. In many Japanese local communities newcomers are not allowed to participate in religious festivals and events, what is the case of Matsugasaki Myoho okuribi, for example. These restrictions associate natives as bearers of tradition and set boundaries inside community dividing its members to "insiders" and "outsiders" in respect to the true and full community membership. The distinguishing feature in Matsugasaki is that newcomers are actively involved in some local celebrations, examples of which are difficult to find in other similar communities in Kyoto city. Thanks to the entrepreneurial spirit and initiatives of the both sides, the children of the newcomers, as well as their parents, know the local traditions and respect them as their own. The only exceptions are rituals, performed during Obon period, because of their deep roots and connections to the local past and traditions of honke.

Local communities, with its own structures, leaders, active peoples, together with local institutions like schools, municipality, etc. are building and maintaining the foundation of matsuri as a keystone of local identity, solidarity and culture. Without proper and working institutions and collaboration with them local community could not preserve its festivals. Peoples' motivation to participate in matsuri could not be understood without explaining the role of local community's structures that are supporting and organizing their activities. Local community is the social structure which is the necessary basis for realization of their activities.

The specificity of a society is determined by its social structures and institutions; they are the foundation on which the national culture and identity are built, maintained and developed. In terms of local festivals, the local community with its institutions, structures, leaders and active local people are the driving force that organizes, preserves, conducts and continues over the years and transmits from generation to generation local traditions and identity. They create and preserve the cultural history of the community, and local celebrations are the visible expression, the embodiment of this cultural history. This history has been re-written and re-narrated by every generation and local community is a social structure which is transmitting it through the centuries. As the community is the subject, the bearer of the local cultural history, the changes in the community cause changes in the culture itself and lead to a rethinking of traditions, rituals and customs, some of which have been 
perceived as unchanged for centuries. The purpose of the changes is to preserve the community and strengthen the solidarity between its members on the basis of the new type of relationships that is being built between them.

\section{References}

Ajisaka, M. (2012). Local organizations and groups in Japan - chiefly in neighborhood associations (chonaikai, jichikai). Doshisha University Press. https://www.academia.edu/7568978/LOCAL_ORGANIZATIONS_AND_GROUPS IN_JAPAN_Chiefly_in_Neighborhood_Associations_Chonaikai_Jichikai

Ashkenazi, M. (1993). Matsuri: festivals of a Japanese town. University of Hawaii Press. https://www.amazon.com/Matsuri-Festivals-Japanese-MichaelAshkenazi/dp/0824814215

Bell, C. (1992). Ritual theory, ritual practice. Oxford University Press. https://www.amazon.com/Ritual-Theory-Practice-Catherine-Bell/dp/0199733627

Bellah, R., Madsen, R., Sullivan, W. M., Swidler, A. \& Tipton, S. M. (1985). Habits of the heart. Individualism and commitment in American life. University of California Press. https://www.amazon.com/Habits-Heart-Individualism-CommitmentAmerican/dp/0520254198

Bestor, T. C. (1989). Neighborhood Tokyo. Stanford University Press. https://www.sup.org/books/title/?id=2454

Dore, R. P. (1958). City life in Japan: a study of a Tokyo Ward. Routledge. https://www.routledge.com/City-Life-in-Japan-A-Study-of-a-TokyoWard/Dore/p/book/9780415846585

Durkheim, E. (2001). The elementary forms of religious life. Oxford University press. (Originally work published 1912) https://www.amazon.com/Elementary-Forms-Religious-Life/dp/0199540128

Etzioni, A. (1993). The spirit of community: the reinvention of american society. Touchstone. https://books.google.bg/books/about/Spirit_Of_Community.html?id=7Gj9kL2XNacC $\underline{\text { \&redir_esc }=\mathrm{y}}$

Hobsbawm, E. (1983). The invention of tradition. In E. Hobsbawm \& T. Ranger (Eds.), The Invention of Tradition (pp.1-14). Cambridge University Press. 
http://psi424.cankaya.edu.tr/uploads/files/Hobsbawm_and_Ranger_eds_The_Inventio n_of_Tradition.pdf

Keliyan, M. (2010). Stil na jhivot na lokalnata obshtnost: savremenna Yaponiya [Local Community Lifestyle: Contemporary Japan]. Alex Print.

https://www.book.store.bg/p44304/stil-na-zhivot-na-lokalnata-obshtnost-syvremennaiaponia-maia-kelian.html

Lewis, D. C. (2018). Religion in japanese daily life. Routledge.

https://www.routledge.com/Religion-in-Japanese-Daily-

Life/Lewis/p/book/9780367878016

Matsuda, M. (1998). Urbanization from below: creativity and self resistance in the everyday life of maragoli migrants in Nairobi. Kyoto University Press.

https://www.worldcat.org/title/urbanisation-from-below-creativity-and-soft$\underline{\text { resistance-in-the-everyday-life-of-maragoli-migrants-in-nairobi/oclc/42687095 }}$

Nelson, J. K. (1996). A year in the life of a Shinto Shrine. University of Washington Press. https://www.amazon.com/Year-Life-Shinto-Shrine/dp/0295975008

Pekkanen, R. J., Tsujinaka, Y. \& Yamamoto, H. (2014). Neighborhood associations and local governance in Japan. Routlegde.

https://www.routledge.com/Neighborhood-Associations-and-Local-Governance-inJapan/Pekkanen-Tsujinaka-Yamamoto/p/book/9781138089488

Plutschow, H. \& O’Neil, P. G. (1996). Matsuri: the festivals of Japan. Routledge. https://www.routledge.com/Matsuri-The-Festivals-of-Japan-With-a-Selection-fromPG-ONeills-Photographic/Plutschow/p/book/9781873410639

Porcu, E. (2012). 'Observations on the blurring of the religious and the secular in a Japanese urban setting'. Journal of Religion in Japan, 1(1), 83-106. https://brill.com/view/journals/jrj/1/1/article-p83_6.xml

Robertson, J. (1991). Native and newcomer: making and remaking a Japanese city. University of California Press. https://www.ucpress.edu/book/9780520086555/native-and-newcomer

Yanagita, K. (1988). About our ancestors: The Japanese family system. Greenwood Press. https://www.worldcat.org/title/about-our-ancestors-the-japanese-familysystem/oclc/18324976 